九州大学学術情報リポジトリ

Kyushu University Institutional Repository

\title{
A Preliminary Study on Cross Breeding of Acid Citrus with Reference to Juice Qualities and Physical Fruit Characteristics
}

Widodo, Soesiladi E.

Fruit Science Laboratory, Faculty of Agriculture, Kyushu University

Shiraishi, Mikio

Fruit Science Laboratory, Faculty of Agriculture, Kyushu University

Shiraishi, Shinichi

Fruit Science Laboratory, Faculty of Agriculture, Kyushu University

https://doi.org/10.5109/24098

出版情報 : 九州大学大学院農学研究院紀要. 40 (1/2)，pp. 105-115，1995-12. Kyushu University バージョン：

権利関係 : 


\title{
A Preliminary Study on Cross Breeding of Acid Citrus with Reference to Juice Qualities and Physical Fruit Characteristics
}

\author{
Soesiladi E. Widodo, Mikio Shiraishi and Shinichi Shiraishi \\ Fruit Science Laboratory, Faculty of Agriculture, \\ Kyushu University Fukuoka 81 1-23, Japan \\ (Recened July 26,1995)
}

\begin{abstract}
Fruits of F-1 progenies of high-acid citrus and their parents were evaluated in 1992, 1993, and 1994 for their juice quality and physical fruit characteristics. After statistical adjustment for yearly variation, the results show that most progenies possessed high acidity but, the fruits were much smaller and lighter than their large or heavy fruit parents. Based on the degree of color development, early or late maturity seemed to be inherited. Peel weight of the progenies was widely distributed toward as light as the lightest, parents and as heavy as the heaviest ones. The juice weight was similarly distributed as peel weight. Fruit shape was skew-distributed toward globose or oblate.
\end{abstract}

\section{INTRODUCTION}

Quantitave genetic analysis has been a major method of interest in studying inheritances of traits in many horticultural crops. From the analysis, heritability and the nature of genetic variances of many traits as genetic basis in selecting promising parents and progenies for breeding programs are known in vegetables such as cucumber (McCreight et al., 1978) and tomato (Wessel-Beaver and Scott, 1992), fruits such as sweet cherry (Hansche et al., 1966 and 1975), apple (Klein, 1958), avocado (Lavi et al., 1991 and 1993), blueberry (Finn and Luby, 1992), peach (Hansche et al., 1972a), and nuts such as almond (Kester et al., 1977), walnut (Hansche et al., 1972b), and pecan (Thompson and Baker, 1993). A method of study in Mendelian genetics may also result in significant contributions for breeding programs such as used in apple (Kimball, 1930; Bishop, 1961; Nybom, 1959). However, the genetic basis and mode of inheritance of most fruit quality traits in citrus are still unknown although planned and documented studies of breeding and genetic have been recorded since 1893 (Cameron and Frost,, 1968).

A low acidity imparted by a low-acid pummelo (Citrus grandis L. Osbeck) has received a great deal of interest in developing 'table' citrus having high soluble solids-acid ratios (Soost and Cameron, 1961; Cameron and Soost, 1974, 1977, and 1979). In Japan, as an easy-peeled, good-looking 'table' citrus is preferred, the inheritances of peeling (Yamamoto et al., 1988) and peel texture (Yamamoto et al., 1990) were studied. Until reports on the heritability and the nature of genetic variances of citrus traits are available, citrus breeders depend mostly only on some known-inheritance of limited citrus species in selecting parents and progenies.

Comparing with 'table' citrus, acid citrus is less treated by any breeding program. An acid citrus breeding program was recorded in 1924, but the program was soon terminated (Cameron and Frost, 1968). Since then, no hybrids of acid citrus have been developed via 
sexual hybridization. Efforts to develop hybrids of acid citrus have been on record in Japan (Koike, 1993; Koike and Yamao, 1992). However, their data are extremely limited to give a thourough picture of the genetic aspect in acid citrus breeding.

Unlike 'table' citrus, high acidity is preferred in acid citrus. Together with juice percentage, it determines the juice quality demanded by juice processors. Besides, physical fruit characteristics are also important. Fruit size and fruit weight determine the number of fruit per carton. Fruit shape is also an important factor as slices of acid citrus are often served in salads and other dishes; an ellipsoid shape may give more slices than globose or oblate. With the existing condition of mostly unknown inheritance of fruit quality traits, breeding studies in acid citrus are left further behind and breeders are left with few clues for selecting promising parents and progenies, especially for juice quality traits.

The present paper reports juice qualities and physical fruit characteristics of F-1 progenies from crosses of several acid citrus evaluated in 1992, 1993, and 1994. These results may provide some guidelines for others who are carrying on acid citrus breeding programs.

\section{MATERIALS AND METHODS}

The materials used in this study were sampled from progenies grown at the Fruit Trees Experiment Station of Kyushu University in November 16, 1992, 1993, and 1994. The progenies were budded on Satsuma mandarin (Citrus unshiu Marc.). The parents crossed were Hanayu (C. hanayu Hort. ex Shirai), Kabosu (C. sphaerocarpa Hort. ex Tanaka), Sudachi (C. sudachi Hort. ex Shirai), Yuzu (C. junos Sieb. ex Tanaka), Daidai (C. aurantium Linn. var Cyanthifera Y. Tanaka), 'Lisbon' lemon (C. limon Burm. f. Lisbon), 'Kusaie' lime (C. limonia Osbeck f. Kusaie), 'Ethrog' citron (C. medica var Ethrog Engl.) and Chinotto 'citrange' (a description given by Hodgson, 1967, indicates that our Chinotto seems to be a dwarf Chinotto of myrtle-leaf orange, C. myrtifolia Rafinesque, not a citrange). With a relatively high sugar content and a low acidity, the Chinotto is not an acid citrus but as it produced progenies with a high acid level it is included in this study. In all parents and progenies, when the number of fruits exceeded 10 fruits, 10 fruits were sampled randomly around the canopy. Otherwise, all available fruits were used. The fruits were peeled, the juice was extracted with a hand-pressed juicer and then centrifuged at 2,500 rpm for 20 minutes. A hundred $\mathrm{ml}$ of the supernatant juice was used for analyses. Fruit, peel, and juice of the samples were weighed individually. Fruit size as a fruit diameter plus fruit height was developed as suggested by Lentz (1967).

Total sugar content was determined as follows: $4 \mathrm{ml}$ of deionized water was added to $1 \mathrm{ml}$ juice, and then $5 \mathrm{ml}$ of $4 \% \mathrm{H}_{3} \mathrm{SO}_{4}$ was added into it. After boiling for 30 minutes, this solution was neutralized with $2 \mathrm{~N} \mathrm{NaOH}$. This solution was then treated as in the reducing sugar determination of the modified procedure of Bertrand (Shiraishi, 1993). Total acid content was determined in $1 \mathrm{ml}$ juice by titration with $0.1 \mathrm{~N} \mathrm{NaOH}$ and phenolphthalein as indicator after passage through a column $(1.6 \mathrm{~cm} \mathrm{I} . \mathrm{D} . \times 4 \mathrm{~cm})$ of cation-exchange resin Amberlite IR-120. 
Yearly differences are known to add considerably to the variability of characters in many plants (Hansche et al., 1966, 1972a and 1972b; Shiraishi, 1995; Thompson and Baker, 1993). To minimize this source of error, least-square estimates of year effects were obtained and all measurements were adjusted accordingly. The statistical procedures for obtaining the estimates are those applicable to non-orthogonal experiments with unequal number of observation within cells and with missing cells. The use of these methods has been discussed and described in detail by Henderson (1953) and later by Searle and Henderson (1961).

The appropriate statistical model from which available data provided least squares estimates of year effects, $\mathrm{Y}_{,,}=\mu+g,+y_{1}+(g y)_{\text {. }} ; i=1,2, \ldots q, j=1,2, r$, and $k=0,1$,

$s$, has been described elsewhere (Hansche et al., 1966 and Hansche et al., 1972a). The number of genotype, $q$, was a total of 102, consisting of 9 parents and 93 progenies, and the number of year, $r$, was 3 . The total number of observations over genotypes and years varied from traits to traits between 414 and 866 . The number of observations of each genotype in each year, s, was either 0 or 3 in sugar and acid measurements, and as low as 0 and as high as 10 in physical fruit measurements. The linear equations for each trait were then solved for $\hat{y}_{j}^{\prime}$ s and the data were adjusted accordingly; $i$. e., $\hat{Y}_{i j h}=\mathrm{Y}_{,,},-\hat{y}_{j}$.

\section{RESULTS AND DISCUSSION}

The performances of progenies were markedly affected by yearly differences (Table 1). These annual variations complicate the discrimination of progeny differences when comparisons are made on progeny's performances in different years. The statistical removal of these effects would be expected to increase the ability to discriminate the progenies and simplify the analysis.

Juice qualities and physical fruit characteristics of the parents used are shown in Table 2. The acid citrus used had a very high acidity, higher than obtained by Yamaki (1988 and 1989), but the acidity of Yuzu agreed with Sawamura et al. (1986). A wide difference in total sugar content was present. During maturation, an increase in sugar content might have occured while acidity was decreasing. At harvest, Chinotto and Daidai were still green and Lisbon was yellowish green, while other parents had been in a yellow

\begin{tabular}{lrr} 
Table 1. Least square estimates of year effect for fruit, qualities'. & 1993 \\
\hline Fruit qualities & 1992 & 199 \\
Total acid content & -11.60 & -3.91 \\
Total sugar content & -7.78 & -4.38 \\
Fruit size' & 0.18 & 0.08 \\
Fruit weight & 12.38 & 4.05 \\
Peel weight & 5.46 & 4.58 \\
Juice weight & 3.88 & 0.14 \\
Fruit shape index &
\end{tabular}

'Least square estimate of year effect in 1994 was set to zero;

'Fruit diameter plus fruit height; "Fruit diameter-to-fruit height ratio 
Table 2. Juice qualities and physical fruit characteristics of the parents".

\begin{tabular}{|c|c|c|c|c|c|c|c|c|}
\hline & $\begin{array}{c}\mathrm{TA}^{\prime} \\
---(\end{array}$ & 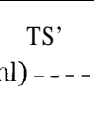 & $\begin{array}{l}\text { Fruit } \\
\text { color" }\end{array}$ & $\begin{array}{l}\text { Fruit } \\
\text { size } \\
(\mathrm{cm})\end{array}$ & $\begin{array}{c}\text { Fruit } \\
\text { weight } \\
\text { (g/fruit) }\end{array}$ & $\begin{array}{c}\text { Peel } \\
\text { weight' } \\
(\%)\end{array}$ & $\begin{array}{c}\text { Juice } \\
\text { weight' } \\
(\%)\end{array}$ & FSI \\
\hline Chinotto & 18.63 & 58.39 & Green & 8.23 & 36.73 & 29.10 & 31.53 & 1.09 \\
\hline Sudachi & 60.94 & 44.18 & Yellow & 7.65 & 31.39 & 25.29 & 33.35 & 1.24 \\
\hline Kabosu & 55.50 & 36.04 & Yellow & 12.49 & 136.76 & 32.98 & 34.73 & 1.20 \\
\hline Daidai & 54.63 & 35.16 & Green & 16.17 & 224.70 & 40.65 & 33.24 & 1.09 \\
\hline Yuzu & 61.91 & 25.54 & Yellow & 12.16 & 126.54 & 39.12 & 19.84 & 1.27 \\
\hline Hanayu & 67.07 & 24.62 & Yellow & 9.44 & 45.88 & 35.29 & 25.78 & 1.11 \\
\hline Lisbon & 74.30 & 16.89 & yGreen & 15.84 & 110.93 & 37.16 & 29.00 & 0.77 \\
\hline Citron & 71.19 & 18.32 & Yellow & 17.11 & 256.35 & 48.11 & 17.77 & 0.71 \\
\hline Kusaie & 74.92 & 12.42 & Yellow & 7.37 & 25.43 & 24.26 & 39.83 & 0.98 \\
\hline
\end{tabular}

" Data after year-effect adjustment; 'TA and TS are total acid and total suger contents, respectively;

"Fruit color in November 16, 1992, 1993, and 1994. Yellow includes its advanced color such as yellowish orange; " Fruit. diameter plus fruit height.; 'As \% of fruit wt. data after year effect adjustment; * Fruit shape index, a fruit diameter-to-fruit height ratio.

stage. The parents were clearly distinguisable on their physical fruit characteristics. The fruit size of Citron, Lisbon, and Daidai was the biggest, Kabosu and Yuzu were medium, and Chinotto, Sudachi, Hanayu, and Kusaie were the smallest. The heaviest fruits were those of Daidai and 'Ethrog' citron, but they had the thickest peel. Kusaie was the smallest with the thinnest peel but contained the highest percentage of juice. The citron had the least juice content, almost similar to the juice of Yuzu. A study on fruit qualities of lemon from various countries of origin conducted by McDonald and Hillebrand (1980) showed that the largest fruit had the thickest peel together with a lower percentage of juice. The shape of Lisbon and citron was ellipsoid, Kusaie was globose, Daidai and Chinotto were less oblate than Sudachi, Kabosu, and Yuzu.

Frequency distribution of total acid and total sugar contents of the progenies are shown in Table 3. Of total progenies examined, $70.27 \%$ had an acidity as high as their parents, and $79.57 \%$ had a sugar content ranged between 11 and $50 \mathrm{mg} / \mathrm{ml}$, which was also the range of sugar content of the parents. It should be noted, however, that the progenies were harvested at the same time so that some progenies might have been overriped. Of total progenies, $63.44 \%$ was in a yellow stage (Table 4). It means that the actual number of progenies of high acidity could be much higher than the presented data. Soost and Cameron (1961) reported that a low-acid pummelo crossed with several mandarin and orange varieties produced hybrids of moderate acidity, while acid pummelos produced hybrids of high acidity. In apple, sweet flavor was known to be determined by one, commonly occuring, recessive gene (Nybom, 1959).

As shown previously in Table 2, the fruits of Chinotto, Daidai, and Lisbon were not as mature as those of other acid citrus investigated on the time of harvest. The fruits of Kabosu, Hanayu, Yuzu, and Sudachi are known to develop yellow color around October, earlier than the fruit of Lisbon of the same age, and much earlier than Daidai. These differences seemed to be inherited to the progenies (Table 4). Kabosu, Hanayu, Yuzu, and 
Table 3. Frequency distribution of total acid and total suger contents among the progenies.

\begin{tabular}{|c|c|c|c|c|c|c|c|c|c|}
\hline \multirow[t]{2}{*}{$\begin{array}{l}\text { Seed } \\
\text { parent }\end{array}$} & \multirow[t]{2}{*}{$\begin{array}{l}\text { Pollen } \\
\text { parent }\end{array}$} & \multicolumn{4}{|c|}{$\begin{array}{c}\text { Total acid content, } \\
(\mathrm{mg} / \mathrm{ml})\end{array}$} & \multicolumn{4}{|c|}{$\begin{array}{c}\text { Total } \underset{(\mathrm{mg} / \mathrm{ml})}{\text { sugar content }} \\
\end{array}$} \\
\hline & & $\overline{430}$ & $31-50$ & $51-70$ & 271 & 110 & $11-30$ & $31-50$ & $\geq 5$ \\
\hline Daidai & Lisbon & & 1 & 1 & 2 & 2 & 1 & 1 & \\
\hline \multirow[t]{4}{*}{ Lisbon } & Daidai & & & 1 & 1 & & 1 & 1 & - \\
\hline & Kabosu & & 2 & 7 & - & & 5 & 3 & 1 \\
\hline & Sudachi & - & 1 & 1 & 2 & 1 & 2 & 1 & \\
\hline & Yuzu & & & 3 & 3 & 1 & 4 & 1 & $=$ \\
\hline \multirow[t]{5}{*}{ Hanayu } & Chinotto & - & 2 & 2 & - & & 2 & 1 & \\
\hline & Kabosu & 1 & 6 & 7 & 3 & 1 & 6 & 6 & 4 \\
\hline & Lisbon & & & 4 & 5 & 5 & 4 & - & \\
\hline & Sudachi & & 1 & 2 & 1 & & 2 & 2 & \\
\hline & Yuzu & & 1 & 4 & 3 & 1 & 3 & 3 & 1 \\
\hline \multirow[t]{3}{*}{ Sudachi } & Kabosu & & 2 & 3 & & & & 4 & 1 \\
\hline & Lisbon & & 1 & & & & & & 1 \\
\hline & Yuzu & & 3 & 2 & - & - & 1 & 4 & \\
\hline \multirow[t]{6}{*}{ Yuzu } & Citron & & & 1 & & & 1 & & \\
\hline & Daidai & & 1 & - & - & & & 1 & - \\
\hline & Kabosu & & & 2 & - & & 1 & 1 & \\
\hline & Kusaie & & & 7 & 1 & & 6 & 2 & - \\
\hline & Lisbon & & & 2 & - & & 1 & 1 & \\
\hline & Sudachi & & 1 & 1 & - & - & 1 & 1 & - \\
\hline
\end{tabular}

Table 4. Frequency distribution of fruit color among the progenies.

\begin{tabular}{|c|c|c|c|c|c|}
\hline \multirow{2}{*}{$\begin{array}{l}\text { Seed } \\
\text { parent }\end{array}$} & \multirow{2}{*}{$\begin{array}{l}\text { Pollen } \\
\text { parent }\end{array}$} & \multicolumn{4}{|c|}{ Fruit color } \\
\hline & & Green & Green & "Yellow & Yellow \\
\hline Daidai & Lisbon & 3 & 1 & & \\
\hline \multirow[t]{4}{*}{ Lisbon } & Daidai & 1 & 1 & & \\
\hline & Kabosu & 1 & 4 & & 4 \\
\hline & Sudachi & & 1 & & 3 \\
\hline & Yuzu & & & & 6 \\
\hline \multirow[t]{5}{*}{ Hanayu } & Chinotto & - & & 2 & 1 \\
\hline & Kabosu & & 1 & 3 & 13 \\
\hline & Lisbon & 2 & 4 & 1 & 2 \\
\hline & Sudachi & & & 1 & 3 \\
\hline & Yuzu & 1 & & 1 & 6 \\
\hline \multirow[t]{3}{*}{ Sudachi } & Kabosu & & & & 5 \\
\hline & Lisbon & & & & \\
\hline & Yuzu & & & 1 & 4 \\
\hline \multirow[t]{5}{*}{ Yuzu } & Citron & & & & 1 \\
\hline & Daidai & & 1 & & \\
\hline & Kabosu & & & & \\
\hline & Kusaie & & 2 & 1 & $\begin{array}{l}5 \\
2\end{array}$ \\
\hline & $\begin{array}{l}\text { Lisbon } \\
\text { Sudachi }\end{array}$ & 1 & & & $\begin{array}{l}2 \\
1\end{array}$ \\
\hline
\end{tabular}

"Green=yellowish green; „Yellow=greenish yellow; yellow includes its advanced color such as yellowish orange. 
Table 5. Frequency distribution of fruit size among the progenies.

\begin{tabular}{|c|c|c|c|c|c|c|}
\hline \multirow{2}{*}{$\begin{array}{l}\text { Seed } \\
\text { parent }\end{array}$} & \multirow{2}{*}{$\begin{array}{l}\text { Pollen } \\
\text { parent }\end{array}$} & \multicolumn{5}{|c|}{ Fruit size $(\mathrm{cm})^{\prime}$} \\
\hline & & $\leq 6$ & $7-10$ & $11-14$ & $15-18$ & 219 \\
\hline \multicolumn{7}{|c|}{$\begin{array}{l}\text { Crossings among } \\
\text { parents of big } \\
\text { and/or medium } \\
\text { size fruits: }\end{array}$} \\
\hline Daidai & Lisbon & & 2 & 1 & 1 & \\
\hline \multirow[t]{3}{*}{ Lisbon } & Daidai & & & & & 1 \\
\hline & Kabosu & & 3 & 5 & 1 & \\
\hline & Yuzu & & 1 & 4 & 1 & \\
\hline \multirow[t]{5}{*}{ Yuzu } & Citron & & & 1 & & \\
\hline & Daidai & & 1 & & & \\
\hline & Kabosu & & 2 & & & \\
\hline & Lisbon & & 2 & & & \\
\hline & & $(0)$ & (12) & (11) & (3) & (1) \\
\hline \multicolumn{7}{|c|}{$\begin{array}{l}\text { Crossings with } \\
\text { parents of small } \\
\text { size fruits: }\end{array}$} \\
\hline Lisbon & Sudachi & & 1 & 3 & & \\
\hline \multirow[t]{5}{*}{ Hanayu } & Chinotto & & 3 & & & \\
\hline & Kabosu & & 14 & 3 & & - \\
\hline & Lisbon & & 6 & 3 & & \\
\hline & Sudachi & & 4 & & & \\
\hline & Yuzu & & 8 & & & \\
\hline \multirow[t]{3}{*}{ Sudachi } & Kabosu & & 4 & & & \\
\hline & Lisbon & & 1 & & & \\
\hline & Yuzu & & 4 & & & \\
\hline \multirow[t]{2}{*}{ Yuzu } & Kusaie & & 8 & & & \\
\hline & Sudachi & (1) & $(53)$ & $\begin{array}{c}2 \\
(12)\end{array}$ & $(0)$ & $(0)$ \\
\hline
\end{tabular}

Fruit diameter plus fruit height. Numbers in parentheses are total frequency distributions.

Sudachi seemed to transfer a factor of early maturity to their progenies. Of 93 progenies, $63.44 \%$ had developed yellow color and its advanced color, such as yellowish orange. Daidai and Lisbon, on the other hand, seemed to transfer late maturity to their progenies. High heritability and additive genetic variation of maturity were found in sweet cherry (Hansche et al., 1966) and peach (Hansche et al., 1972a).

Fruit size was skew-distributed toward smaller size (Table 5). Parents having medium and big size fruits seemed to carry also a factor controlling a small size. They produced $44.44 \%$ of progenies with small fruits. Crossing parents having small fruits such as Sudachi, Hanayu, Chinotto, and Kusaie with parents having medium or big fruits produced much more progenies having fruit size as small as the small fruit parents. The 
Table 6. Frequency distribution of fruit weight among the progenies.

\begin{tabular}{|c|c|c|c|c|c|c|c|c|}
\hline \multirow{2}{*}{$\begin{array}{l}\text { Seed } \\
\text { parent }\end{array}$} & \multirow{2}{*}{$\begin{array}{l}\text { Pollen } \\
\text { parent }\end{array}$} & \multicolumn{7}{|c|}{ Fruit weight (g/ fruit)" } \\
\hline & & $\leq 20$ & $21-50$ & $51-80$ & $81-110$ & $111-140$ & $141-170$ & 1171 \\
\hline \multicolumn{9}{|c|}{$\begin{array}{l}\text { Crossings among } \\
\text { parents of heavy } \\
\text { and/or medium } \\
\text { fruits: }\end{array}$} \\
\hline Daidai & Lisbon & & & 2 & 1 & & & \\
\hline \multirow[t]{3}{*}{ Lisbon } & Daidai & & 1 & & & & & \\
\hline & Kabosu & & 1 & 4 & 2 & 1 & 1 & \\
\hline & Yuzu & & 1 & 1 & 2 & & 1 & \\
\hline \multirow[t]{4}{*}{ Yuzu } & Citron & & & & & & 1 & \\
\hline & Daidai & & & 1 & & & & \\
\hline & Kabosu & & 1 & 1 & & & & \\
\hline & Lisbon & $(0)$ & $\begin{array}{c}1 \\
(5)\end{array}$ & $\begin{array}{c}1 \\
(10)\end{array}$ & (5) & (1) & (3) & (3) \\
\hline \multicolumn{9}{|c|}{$\begin{array}{l}\text { Crossings with } \\
\text { parents of light } \\
\text { fruits: }\end{array}$} \\
\hline Lisbon & Sudachi & & & 3 & 1 & & & \\
\hline \multirow[t]{5}{*}{ Hanayu } & Chinotto & & 2 & 1 & & & & \\
\hline & Kabosu & 1 & 10 & 5 & 1 & & & \\
\hline & Lisbon & 1 & 4 & 3 & 1 & & & \\
\hline & Sudachi & 1 & 2 & 1 & & & & \\
\hline & Yuzu & 1 & 4 & 3 & & & & \\
\hline \multirow[t]{3}{*}{ Sudachi } & Kabosu & & 3 & 2 & & & & \\
\hline & Lisbon & & & 1 & & & & \\
\hline & Yuzu & & 2 & 3 & & & & \\
\hline \multirow[t]{3}{*}{ Yuzu } & Kusaie & & 8 & & & & & \\
\hline & Sudachi & & & & 1 & 1 & & \\
\hline & & (4) & (35) & (22) & (4) & (1) & (0) & $(0)$ \\
\hline
\end{tabular}

"Numbers in parantheses are total frequency distributions.

same tendency was found in fruit weight (Table 6). Crossings among parents having fruits of heavy or medium weight produced more progenies with much lighter fruits. When a progeny with light fruit was used as a parent, the progenies were distributed toward the light fruit parent. In apple, factors which determine small size appear to be dominant to those which tend to produce large size (Klein, 1958; Bishop, 1961).

The fruit shape index was skew-distributed toward globose and oblate (Table 7). Only $21.05 \%$ of the total progenies of Lisbon and citron had the fruit shape of Lisbon or citron. No ellipsoid progeny was produced from crossings among globose and/or oblate parents. Klein (1958) found that the tendency toward roundness or oblateness was dominant to the tendency toward length. 
Table 7. Frequency distribution of fruit shape index among the progenies.

\begin{tabular}{|c|c|c|c|c|}
\hline \multirow{2}{*}{$\begin{array}{l}\text { Seed } \\
\text { parent }\end{array}$} & \multirow{2}{*}{$\begin{array}{l}\text { Pollen } \\
\text { parent }\end{array}$} & \multicolumn{3}{|c|}{ Fruit shape index" } \\
\hline & & $\begin{array}{c}\text { Ellipsoid } \\
(\leq 0.8)\end{array}$ & $\begin{array}{c}\text { Globose } \\
(0.9-1.1)\end{array}$ & $\begin{array}{l}\text { Oblate } \\
(\geq 1.2)\end{array}$ \\
\hline \multicolumn{5}{|c|}{$\begin{array}{l}\text { Crossings with an } \\
\text { ellipsoid parent: }\end{array}$} \\
\hline Daidai & Lisbon & & 4 & \\
\hline \multirow[t]{4}{*}{ Lisbon } & Daidai & 2 & & \\
\hline & Kabosu & 3 & 6 & \\
\hline & $\mathrm{u} \mathrm{d} \mathrm{a} \mathrm{c} \mathrm{h} \mathrm{i}$ & & 4 & \\
\hline & Yuzu & 2 & 4 & \\
\hline Hanayu & Lisbon & 1 & 5 & 3 \\
\hline Sudachi & Lisbon & & 1 & \\
\hline \multirow[t]{3}{*}{ Yuzu } & Citron & & 1 & \\
\hline & Lisbon & & 1 & \\
\hline & & (8) & (26) & (4) \\
\hline \multicolumn{5}{|c|}{$\begin{array}{l}\text { Crossings among } \\
\text { globose and/or oblate } \\
\text { parents: }\end{array}$} \\
\hline \multirow[t]{4}{*}{ Hanayu } & Chinotto & & 2 & \\
\hline & Kabosu & & 11 & 6 \\
\hline & Sudachi & & 2 & 2 \\
\hline & Yuzu & & 4 & 4 \\
\hline \multirow[t]{2}{*}{ Sudachi } & Kabosu & & 4 & \\
\hline & Yuzu & & 3 & 2 \\
\hline \multirow[t]{5}{*}{ Yuzu } & Daidai & & & \\
\hline & Kabosu & & & 2 \\
\hline & Kusaie & & 6 & 2 \\
\hline & Sudachi & & & 2 \\
\hline & & $(0)$ & (32) & (23) \\
\hline
\end{tabular}

* Fruit diameter-to-fruit height ratio. Numbers in parantheses are total frequency distributions

Peel weight was distributed to as light as the peel of Kusaie or Sudachi and as heavy as that of citron and Daidai (Table 8). Regardless of the parents crossed, both progenies having lighter and heavier peel than the parents were produced. A similar distribution was also noted on juice weight (Table 8). The International Standardisation for citrus fruit requires a minimum juice content of $25 \%$ for acid fruit other than lemons (OECD, 1971). Based on this standard value, $84.95 \%$ of the progenies passed the minimum standard.

A great heterozygous nature and a quantitative inheritance of most characters are known in citrus (Cameron and Frost, 1968). These natures were observed in all traits we examined. These indicate that a wide genetic resource is present in acid citrus. Factors controlling high acidity seemed to be less complex than those controlling physical fruit characters. A high acidity imparted by acid pummelos to their progenies was reported by 
Table 8. Frequency distribution of peel and juice weights" among the progenies.

\begin{tabular}{|c|c|c|c|c|c|c|c|c|c|}
\hline \multirow{2}{*}{$\begin{array}{l}\text { Seed } \\
\text { parent }\end{array}$} & \multirow{2}{*}{$\begin{array}{l}\text { Pollen } \\
\text { parent }\end{array}$} & \multicolumn{4}{|c|}{ Peel wt. (\%) } & \multicolumn{4}{|c|}{ Juice wt.(\%) } \\
\hline & & $\leq 29$ & $30-35$ & $36-41$ & $\geq 42$ & 119 & $20-28$ & $29-37$ & $\geq 38$ \\
\hline Daidai & Lisbon & 1 & & 1 & 2 & & 3 & & 1 \\
\hline \multirow{4}{*}{ Lisbon } & Daidai & & & & 1 & & 2 & & \\
\hline & Kabosu & 4 & 2 & & 3 & 3 & 4 & 2 & - \\
\hline & Sudachi & 3 & & & 1 & 1 & 1 & & 2 \\
\hline & Yuzu & 2 & & & 3 & 1 & 2 & 3 & - \\
\hline \multirow[t]{5}{*}{ Hanayu } & Chinotto & 2 & & 1 & - & & 1 & 2 & $=$ \\
\hline & Kabosu & 7 & 5 & 2 & 3 & 2 & 8 & 5 & 2 \\
\hline & Lisbon & 5 & 2 & 2 & $=$ & 2 & 4 & 2 & 1 \\
\hline & Sudachi & 3 & & 1 & - & & & 4 & \\
\hline & Yuzu & 2 & 1 & 3 & 2 & 3 & 5 & & \\
\hline \multirow[t]{3}{*}{ Sudachi } & Kabosu & 4 & 1 & - & - & - & - & 1 & 4 \\
\hline & Lisbon & & 1 & & & & & 1 & - \\
\hline & Yuzu & 3 & 1 & 1 & - & 1 & - & 2 & 2 \\
\hline \multirow[t]{6}{*}{ Yuzu } & Citron & & 1 & & & & 1 & & \\
\hline & Daidai & & & & 1 & & 1 & & \\
\hline & Kabosu & & & & & 1 & - & 1 & \\
\hline & Kusaie & 7 & & 1 & - & & 4 & 2 & 2 \\
\hline & Lisbon & & 1 & & & & 1 & 1 & - \\
\hline & Sudachi & & 1 & & & & 2 & & \\
\hline
\end{tabular}

* As $\%$ of fruit weight, data calculated after year effect adjustment.

Soost and Cameron (1961). A dominant nature of acidity over sweetness was reported in apple (Klein, 1958; Nybom, 1959). As shown in Table 3, more progenies of high acidity than the presented data were possible if they were harvested at their prime maturity.

As shown in Table 5 and 6, more progenies of smaller and lighter fruits were produced. The dominant inheritance of small fruits over large fruits were reported in apple (Klein, 1958; Bishop, 1961). In avocado, due to low additive and non-additive genetic variance of fruit weight, screening among selfing progeny was advised only when decrease of fruit weight is the breeding objective (Lavi et al., 1991). The data presented in Table 5 and 6 suggest that crossing parents having small fruits such as Sudachi, Hanayu, Chinotto, and Kusaie with parents having larger fruits may result in some progenies having larger fruits than the small parents. However, choosing parents based on this character can not be done with certainty due to unavailable information on citrus and variable results found in different plants. High heritability of this character was found in walnut and peach (Hansche et al., 1972a and 1972b) but low to moderate in pecan (Thompson and Baker, 1993), and low in avocado (Lavi et al., 1991 and 1993).

Another significant results suggested from this initial evaluation are early maturity of Hanayu, Sudachi, and Yuzu, and late maturity of Daidai and Lisbon, indicating that a wide genetic variation of maturity is present in acid citrus. Daidai, however, possesses some unfavourable characters such as granulation and a tremendous decrease of acidity during maturation (Yamada and Nishiura, 1977). 
Differences in fragrance are of interest in acid citrus breeding programs dealing with Japanese acid citrus because they have a unique fragrance with different compositions of peel oils (Yang et al., 1992). This may be the field that should receive more attention in acid citrus breeding programs.

\section{ACKNOWLEDGEMENT}

Contributions from the Fruit Tree Experiment Station, Kyushu University at Sasaguri, Fukuoka, Japan are highly appreciated.

\section{REFERENCES}

Bishop, C. J. 1961 A study of male parental influence in crosses with the Northern Spy apple. Proc. Amer.Soc. Hort. Sci., 57: 165-168

Cameron, J. W. and H. B. Frost. 1968 Genetics, breeding, and nucellar embryony. In "The Citrus Industry", Vol. II, ed. by W. Reuther and L. D. Batchelor, Univ. of California, USA, pp. 325-370

Cameron, J. W. and R. K. Soost 1974 Evidence for hybrid vigor in F1 citrus populations with pummelo [Citrus grandis (L.) Osbeck] as one parent. J. Amer. Soc. Hort. $S_{\text {.., }} \mathbf{9 5}(5)$ : 433-435

Cameron, J. W. and R. K. Soost 1977 Acidity and total soluble solids in citrus hybrids and advanced crosses involving acidless orange and acidless pummelo. J. Amer. Soc. Hort. Sci.,102(2): 198-201

Cameron, J. W. and R. K. Soost 1979 Absence of acidless progeny from crosses of acidless $\times$ acidless citrus cultivars. J. Amer. Soc. Hort. Sci., 104(2): 220-222

Finn, C. E. and J. J. Luby 1992 Inheritance of fruit quality traits in blueberry. J. Amer. Soc. Hort. Sci., $117(4): 617-621$

Hansche, P. E., C. 0. Hesse, and V. Beres 1972a Estimates of genetic and environmental effects on several traits in peach. J. Amer. Soc.Hort. Sci., 97(1): 76-79

Hansche, P. E., C. 0. Hesse, and V. Beres 1975 Inheritance of fruit size, soluble solids, and ripening date in Prunusdomestica cv. Agen. J. Amer. Soc. Ilort. Sci., 100(5): 522-524

Hansche, P. E., V. Beres, and H. I. Forde $1972 \mathrm{~b}$ Estimates of quantitative genetic properties of walnut and their implications for cultivar improvement. J. Amer. Soc. Hort. Sci.,97(2): 279-285

Hansche, P. E., V. Beres, and R. M. Brooks 1966 Heritability and genetic correlation in the sweet cherry. Proc. Amer. Soc. Hort. Sci., 88: 173-183

Henderson, C. R. 1953 Estimation of variance and covariance components. Biometrics, 9(2): 226-252

Hodgson, R. W. 1967 Horticultural varieties of citrus. In "The Citrus Industry", Vol. I, ed. by W. H. Reuther, J. Webber, and L. D. Bachelor. Univ. Calif., Division of Agr. Sciences, California, pp. 431-588

Kester, D. E., P. E. Hansche, V. Beres, and R. N. Asay 1977 Variance components and heritability of nut and kernel traits in almond. J.Amer. Soc.Hort.Sci., 102(3): 264-266

Kimbal, D. A. 1930 A study of the progeny resulting from crossing certain apple varieties. Proc. Amer. Soc. Hort. Sci., 27: 412-415

Klein, L. G. 1958 The inheritance of certain fruit characters in the apple. Proc. Amer. Soc. Hort. Sci., 72: 1-14

Koike, A. 1993 A study on acid citrus breeding. Ann. Rep. Ehime Fruit Tree Exp.Stn., pp. 71-72

Koike, A. and M. Yamao 1992 A study on acid citrus breeding. Ann. Rep. Ehime Fruit Tree Exp. Stn., pp. 63-64

Lavi, LJ., E. Lahav, A. Genizi, C. Degani, S. Gazit, and J. Hilel 1991 Quantitative genetic analysis of traits in avocado cultivars. Plant Breeding, 106: 149-160

Lavi, U., E. Lahav, C. Degani, S. Gazit, and J. Hilel 1993 Genetic variance components and heritabilities of several avocado traits. J.Amer. Soy. Hort. Sci.,118(3): 400-404

Lentz, F. 1967 Relationships between the vegetative and reproductive growth of Washington Navel orange cuttings (Citrus sinensis L. Osbeck). J.Hort.Sci., 42: 31-39 
McCreight, J. D., R. L. Lower, R. H. Moll 1978 Heritability of reducing sugar concentration in pickling cucumber fruit and its implication on methods of selection, J. Amer.Soc:Hort.Sci., 103(2): 271-274

McDonald, R. E. and B. M. Hillebrand 1980 Physical and chemical characteristics of lemons from several countries. J.Amer. Soc. Hort. Sci., 105(1): 135141

Nybom, N. 1959 On the inheritance of acidity in cultivated apples. Hereditas 45: 332-350

OECD 1971 International Standardisation of Fruit and Vegetables. Citrus Fruit. Organization for Economic Co-operation and Development, Paris.

Sawamura, M., N. Kuroiwa, T. Kuriyama, and H. Kusunose 1986 Characteristic of Yuzu and seedless Yuzu fruits. Nippon Shokuhin Kogyo Gakkaishi, 33(11): 773-778

Searle, S. R. and C. R. Henderson 1961 Computing procedures for estimating components of variance in the two-way classification, mixed model. Biometrics, 17: 607-616

Shiraishi, M. 1993 Three descriptors for sugars to evaluate grape germplasm. Euphytica, 71: 99-106

Shiraishi, M. 1995 Proposed descriptors for organic acids to evaluate grape germplasm. Euphytica, 81: $13-20$

Soost, R. K. and J. W. Cameron 1961 Contrasting effects of acid and nonacid pummelos on the acidity of hybrid citrus progenies. Hilgardia,30(12): 351-357

Thompson, T. E. and J. F. Baker 1993 Heritability and phenotypic correlations of six pecan nut characteristics. J. Amer. Soc. Hort.Sci., 118(3): 415-418

Wessel-Beaver, L. and J. W. Scott 1992 Genetic variability of fruit set, fruit weight, and yield in a tomato population grown in two high-temperature environments. J.Amer. Soc. Hort. Sci, 117(5): 867-870

Yamada, Y. and M. Nishiura 1977 Investigation of varietal characteristics of citrus fruits. I. Seasonal changes of fruit quality and rind color. Bull.Fruit Tree Res. Sta. B., 4: 1-37

Yamaki, Y. T. 1988 Differences in juice acidities of citrus species and relationships among acidities, and of acidities to potassium concentration. J.Japan.Soc.Hort. Sri., 56(4): 457-469

Yamaki, Y. T. 1989. Organic acids in the juice of citrus fruits. J.Japan.Soc.Hort.Sci, 58(3): 587-594

Yamamoto, M., R. Matsumoto, N. Okudai, and K. Asada 1988 Inheritance of citrus fruit peelings. Bull. Fruit Tree Res. Sta.D. 10: 1-9

Yamamoto, M., R. Matsumoto, N. Okudai, and K. Asada 1990 Segregation for rind texture in citrus hybrid seedlings. J.Japan. Soc. Hort.Sci, 59(1): 15-21

Yang, R., H. Sugisawa, H. Nakatani, H. Tamura, and N. Takagi 1992 Comparison of odor quality in peel oils of acid citrus. Nippon Shokuhin Kogyo Gakkaishi, 39(1): 16-24 